\title{
PERLINDUNGAN HUKUM DAN TANGGUNG JAWAB RUMAH SAKIT TERHADAP DOKTER DALAM SENGKETA MEDIS
}

\author{
Rossi Suparman \\ Sekolah Tinggi Ilmu Kesehatan Kuningan \\ rossisuparman@yahoo.com \\ DOI : https://doi.org/10.29313/shjih.v17i2.5441
}

\begin{abstract}
ABSTRAK
Praktek kesehatan selalu berpotensi menimbulkan resiko hukum bagi dokter dan rumah sakit, resiko, setiap resiko hukum akan menuntut tanggung jawab hukum sehingga persoalan ini perlu dikaji untuk mendapat solusi. Tulisan ini menggunakan metode yuridis normatif dengan menggunakan data sekunder yang dianalisis secara kualitatif. Hasil penelitian (1) Implementasi dari pelaksanaan tanggung jawab rumah sakit terhadap dokter dalam Undang - undang tersebut berbeda - beda, tergantung dari status kepegawaian / ketenagakerjaan dokter, kontrak kerjasama yang telah disepakati antara pihak rumah sakit dengan dokter, status rumah sakit sebagai suatu badan hukum atau korporasi, regulasi, keputusan serta ketetapan internal rumah sakit, peran organisasi profesi dan masyarakat. Konsep penanganan sengketa medik yang ada selama ini, disamping menggunakan cara litigasi, dilakukan juga dengan mengedepankan cara alternatif penyelesaian sengketa diluar pengadilan (non ligitasi). (2) Model yang dapat diterapkan dalam rangka perlindungan hukum dan tanggungjawab rumah sakit terhadap dokter dalam sengketa medik adalah Model yang adil menurut hukum, dimana dokter dibekali kode etik kedokteran, standar profesi, hukum kesehatan, hak asasi manusia, fungsi sosial serta peraturan-peraturan yang mengatur praktik kedokteran; dan rumah sakit harus mempunyai berbagai aturan untuk melindungi pasien dari praktek rumah sakit yang tidak layak beroperasi, melindungi tenaga kesehatan dari bahaya yang ditimbulkan oleh rumah sakit, melindungi masyarakat dari dampak lingkungan rumah sakit, mengendalikan fungsi rumah sakit kearah yang benar, meningkatkan mutu rumah sakit.
\end{abstract}

Kata Kunci : Sengketa Medis, Dokter, Perlindungan, Tanggung Jawab.

\section{ABSTRACT}

Health practice always has the potential to create legal risks for doctors and hospitals, risks, each legal risk will require legal responsibility so this problem needs to be examined to get a solution. This paper uses the normative juridical method using secondary data that is analyzed qualitatively. Research results (1) Implementation of the implementation of hospital responsibilities towards doctors in the Act varies, depending on the doctor's employment / employment status, cooperation contracts that have been agreed between the hospital and the doctor, the hospital's status as a legal entity or corporations, regulations, decisions and internal provisions of the hospital, the role of professional organizations and society. The concept of handling medical disputes so far, besides using litigation, 
is also carried out by promoting alternative ways of resolving disputes outside the court (non-litigation). (2) Models that can be applied in the context of legal protection and responsibility of hospitals to doctors in medical disputes are models that are fair according to the law, where doctors are equipped with codes of medical ethics, professional standards, health laws, human rights, social functions and regulations governing medical practice; and hospitals must have various rules to protect patients from hospital practices that are not feasible to operate, protect health workers from the dangers posed by hospitals, protect the community from the environmental impact of the hospital, control the hospital's functions in the right direction, improve hospital quality .

Keywords: Medical Disputes, Doctors, Protection, Responsibility

\section{A. PENDAHULUAN}

\section{Latar Belakang Masalah}

Masyarakat selalu beranggapan bahwa upaya medis yang dilakukan dokter merupakan satu-satunya variabel yang dapat mempengaruhi kondisi kesakitan pasien, kalau upaya dokter sudah benar menurut logika mereka tidak seharusnya pasien meninggal dunia, bertambah buruk kondisinya atau muncul 'problemproblem' baru. Kenyataannya, upaya medis yang terbaik dan termahal sekalipun belum tentu dapat menjamin kesembuhan, demikian pula sebaliknya. Oleh karena itu, tidaklah salah jika ada yang menyatakan "Medicine Is A Science Of The Uncertainty, An Art Of The Probability", yang artinya pengobatan merupakan ilmu ketidakpastian, yaitu sebuah seni dari berbagai kemungkinan. ${ }^{1}$ Pemahaman yang kurang memadai tentang hakekat upaya medis tersebut salah satunya terjadi karena minimnya pemahaman mengenai hukum. Terjadi perikatan antara pasien dan rumah sakit menyusul disepakatinya hubungan terapeutik yang konsekuensinya memunculkan hak dan kewajiban pada masingmasing pihak. ${ }^{2}$

Perikatan yang terjadi antara penerima pelayanan kesehatan dan pemberi pelayanan kesehatan merupakan perikatan upaya (inspanning verbintenis)

\footnotetext{
Alexandra Indriyanti Dewi, Etika dan Hukum Kesehatan, Pustaka Book Publisher, Yogyakarta, 2008. Hlm. 43.

2 Lihat Soekidjo Notoatmodjo, Etika dan Hukum Kesehatan, Rineka Cipta, 2010. Hlm. 231.
} 
sehingga konsekuensi hukumnya, rumah sakit tidak dibebani kewajiban untuk mewujudkan hasil (berupa kesembuhan) melainkan hanya dibebani kewajiban melakukan upaya sesuai standar (standar of care), yaitu suatu tingkat kualitas pelayanan medis yang mencerminkan telah diterapkannya ilmu, keterampilan, pertimbangan dan perhatian yang layak sebagaimana dilakukan oleh dokter pada umumnya dalam menghadapi situasi dan kondisi yang sama pula. Dengan tingkat kualitas seperti itu diharapkan mampu menyelesaikan problem kesehatan pasien. Akan tetapi, jika pada kenyataannya harapan tersebut tidak terwujud atau bahkan kejadian tidak diharapkan (adverse event); atau resiko medis; atau pasien tidak tersembuhkan; atau meninggal dunia (terminal bed), maka tidak serta merta dokter atau rumah sakit harus dipersalahkan atau tidak dapat dituntut secara hukum guna pertanggungjawaban. ${ }^{3}$

Pasal 45 ayat (2) UU No 44 Tahun 2009 tentang Rumah Sakit menyatakan: "Rumah sakit tidak dapat dituntut dalam melaksanakan tugas dalam rangka menyelamatkan nyawa manusia", Kemudian Pasal 58 ayat (2) Undang-undang Nomor 36 tahun 2009 tentang Kesehatan menyatakan, bahwa "Tuntutan ganti rugi sebagaimana dimaksud pada ayat (1) tidak berlaku bagi tenaga kesehatan yang melakukan tindakan penyelamatan nyawa atau pencegahan kecacatan seseorang dalam keadaan darurat". ${ }^{4}$ Selain itu rumah sakit harus bertanggungjawab dalam ruang lingkup hukum pidana, diantaranya jika tenaga kesehatan yang menjadi pelaksana tugas pelayanan di rumah sakit melakukan kesalahan profesional. ${ }^{5}$ Oleh karena itu rumah sakit harus memberikan perlindungan hukum dan tanggungjawab bagi dokter ketika mendapat tuntutan

3 Abdul Wahab Bakri, Kapita Selekta Hukum Medik, Fakultas Hukum Universitas Islam Bandung, Bandung, 1998. Hlm. 11.

${ }^{4}$ Pasal 58 Undang-Undang Nomor 36 Tahun 2009 tentang Kesehatan ayat (1) " Setiap orang berhak menuntut ganti rugi terhadap seseorang, tenaga kesehatan, dan/atau penyelenggara kesehatan yang menimbulkan kerugian akibat kesalahan atau kelalaian dalam pelayanan yang diterimanya."

${ }^{5}$ Endang Wahyati Yustina, Mengenal Hukum Rumah Sakit, Keni Media Bandung, 2012. Hlm. 90. 
hukum dari masyarakat, sesuai Pasal 29 ayat (1) huruf (s) Undang-undang No 44 tahun 2009 tentang Rumah Sakit yang menyatakan bahwa "Rumah Sakit mempunyai kewajiban melindungi dan memberikan bantuan hukum bagi semua petugas Rumah Sakit dalam melaksanakan tugas”. Selanjutnya Pasal 46 menyebutkan, "Rumah Sakit bertanggung jawab secara hukum terhadap semua kerugian yang ditimbulkan atas kelalaian yang dilakukan oleh tenaga kesehatan di Rumah Sakit”. Pasal 50 huruf (a) Undang-undang Nomor 29 Tahun 2004 tentang Praktik Kedokteran menyatakan bahwa "Dokter atau dokter gigi dalam melaksanakan praktik kedokteran mempunyai hak memperoleh perlindungan hukum dan tanggungjawab sepanjang melaksanakan tugas sesuai dengan standar profesi dan standar prosedur operasional".

Rumah Sakit adalah pihak yang harus memberikan prestasi, sementara dokter hanya berfungsi sebagai employee (subordinate dari rumah sakit) yang bertugas melaksanakan kewajiban Rumah Sakit. ${ }^{6}$ Dalam hal Rumah Sakit pemerintah, maka dokter dan perawat yang bekerja pada Rumah Sakit tersebut tidak menjalankan hak dan kewajibannya sebagai perorangan melainkan hak dan kewajiban Rumah Sakit sebagai badan hukum publik. Sebab tanggungjawab dari semua tindakan yang bersumber dari hak dan kewajiban menjadi tanggungjawab Rumah Sakit. ${ }^{7}$ Salah satu kasus dugaan malpraktek diantaranya Kasus yang dialami oleh dr. D, dr. Dr. H dan dr HN (para terdakwa), awalnya diproses oleh polres kota manado dalam berita acara pemeriksaan nomor. BP/194/X/2010/Reskrim dengan Pasal 359 KUHP jo. Pasal 361 KUHP jo. Pasal 55 KUHP. Pasal 263 KUHP jo. Pasal 55 KUHP. Serta Pasal 76 UU. No 29 Tahun 2004 tentang praktik kedokteran.

6 Dona Budi Kharisma, Aspek Hukum Hubungan Antara Dokter Dengan Rumah Sakit Dalam Perjanjian Terapeutik Di Rumah Sakit Dr. Moewardi Surakarta, Skripsi, UNS, 2008.

7 Ray Pratama Saidarai, Hubungan Pasien, Dokter dan Rumah Sakit, 2004, http://raypratama.blogspot.co.id/2014/11/hubungan-pasien-dokter-dan-rumah-sakit.html, di akses pada tanggal 14 Desember 2015. 
Selanjutnya dituntut oleh jaksa penuntut hukum dengan nomor No.reg.Perk:PDM-43/M.Ndo/Ep.1/09/2010 dengan pasal yang sebagaimana tertuang dalam berita acara pemeriksaan tersebut, yang kemudian kasus ini dibawa ke pengadilan Negeri Manado dengan amar putusan Majelis Hakim menyatakan terdakwa I (dr. D), terdakwa II (dr. H) dan terdakwa III (dr. HN), tidak terbukti secara sah dan meyakinkan bersalah melakukan tindak pidana dalam dakwaan Kesatu primer dan subsidair, dakwaan Kedua dan dakwaan Ketiga primer dan subsidair, membebaskan terdakwa I, Terdakwa II dan Terdakwa III oleh karena itu dari semua dakwaan (Vrijspraak), memulihkan hak para terdakwa dalam kemampuan, kedudukan dan harkat serta martabatnya.

Putusan Majelis Hakim pada Pengadilan Negeri begitu rasional dan objektif dalam melihat persoalan dugaan kesalahan medis yang dilakukan para dokter tersebut, walaupun tidak seutuhnya dalam pertimbangannya menggunakan kajian hukum yang secara langsung memiliki kaitan dengan ruang lingkup profesi kedokteran, sebagai pendekatan dalam memutus kasus tersebut. Akan tetapi kemudian ketika permohonan kasasi Jaksa Penuntut Umum Pada kejaksaan Negeri Manado dikabulkan oleh majelis Hakim Kasasi yang amar putusan Menyatakan Para Terdakwa : dr. D (Terdakwa I), dr. H (Terdakwa II) dan dr. HN (Terdakwa III) telah terbukti secara sah dan meyakinkan bersalah melakukan tindak pidana "Perbuatan yang karena kealpaanya menyebabkan matinya orang lain"; Menjatuhkan pidana terhadap para terdakwa: dr. D (Terdakwa I), dr. H (Terdakwa II) dan dr. HN (Terdakwa III) dengan pidana penjara masing-masing selama 10 (sepuluh) bulan ${ }^{8}$, sedangkan tidak ada vonis apapun yang dijatuhkan terhadap pihak rumah sakit baik unsur pimpinan atau pihak lain yang terkait.

Uraian kasus di atas terlihat bahwa tuntutan tersebut ditujukan pada dokter yang melaksanakan tugasnya di rumah sakit, seharusnya tuntutan tersebut juga

\footnotetext{
${ }^{8}$ Tempo. Co, Hakim PK MA Bebaskan Dokter Ayu, http://www.tempo.co/read/news/2014/02/07/063551992/Hakim-PK, Jakarta, diakses 24 Maret 2014.
} 
dapat diajukan kepada Pimpinan Rumah Sakit. Kondisi ini menjadi perhatian peneliti untuk menganalisis tanggungjawab rumah sakit dalam perlindungan hukum terhadap dokter pada sengketa medis. Oleh karenanya dinilai penting untuk mengadakan penelitian kajian perlindungan hukum dan tanggungjawab rumah sakit terhadap dokter pada sengketa medis dihubungkan.

\section{Identifikasi Masalah}

1. Bagaimana implementasi perlindungan hukum dan tanggungjawab rumah sakit terhadap dokter pada sengketa medis dihubungkan dengan peraturan perundang-undangan dalam upaya mewujudkan keadilan?

2. Bagaimana model perlindungan hukum dan tanggungjawab rumah sakit terhadap dokter pada sengketa medis dalam upaya mewujudkan keadilan?

\section{Metode Penelitian}

Penelitian ini menggunakan pendekatan yuridis normatif berarti usaha mendekati atau mendekatkan masalah yang diteliti melalui permikiran dan telaah refleksi terhadap sifat/karekateristik khusus atau kekhasan hukum Normatif. ${ }^{9}$ Dalam penelitian ini, spesifikasi penelitian yang digunakan adalah deskriptif analisis. Dalam penelitian hukum, hukum memiliki sifat/karakteristik khusus atau kekhasan, yaitu sebagai suatu Norma/kaidah yang mempedomani atau sebagai patokan perilaku manusia dalam berinteraksi dengan sesamanya. ${ }^{10}$ Data dapat diklasifikasikan berdasarkan sifat data dan sumber data.

\section{B. PEMBAHASAN}

9 Soerjono Soekanto \& Sri Mamudji, Penelitian Hukum Normatif (Suatu Tinjauan Singkat), Rajawali Pers, Jakarta, 1985, Hlm. 15.

10 Mukti Fajar dan Yulianto Achamd, Dualisme Penelitian Hukum Normatif dan Empiris, Pustaka Pelajar, Yogyakarta, 2010, Hlm. 138. 


\section{Perlindungan Hukum dan Tanggungjawab Terhadap Profesi Dokter Atas Sengketa Medik Berdasarkan Peraturan Perundang-undangan Indonesia}

Beberapa hal yang dapat dijadikan landasan perlindungan hukum dan tanggungjawab bagi dokter dalam menjalankan profesinya atas sengketa medik, adalah: 1) Adanya norma atau kaidah hukum yang mengaturnya; 2) Adanya hal-hal yang harus dilakukan dokter untuk menghindarkan diri dari tuntutan malpraktik medik; dan 3) Adanya bukti sebagai alasan peniadaan hukuman terhadap dokter atas dugaan malpraktik medik. ${ }^{11}$ Adapun penjelasan dari Ketiga hal tersebut di atas adalah:

a. Norma atau kaidah hukum yang mengatur tentang perlindungan hukum dan tanggungjawab terhadap dokter dalam menjalankan profesi kedokteran atas dugaan malpraktik antara lain:

1) Pasal 50 Undang-Undang Nomor 29 Tahun 2004 Tentang Praktik Kedokteran, Pasal 24 ayat (1), jo Pasal 27 ayat (1);

2) Pasal 29 Undang-Undang Nomor 36 Tahun 2009 Tentang Kesehatan;

3) Pasal 75 Undang-Undang Nomor 36 Tahun 2014 Tentang Tenaga Kesehatan.

b. Hal-hal yang harus dilakukan dokter untuk menghindarkan dari tuntutan malpraktik medik: ${ }^{12}$

1) Informed consent

Dalam menjalankan profesinya informed consent merupakan kewajiban yang harus dipenuhi oleh seorang dokter. Informed consent terdiri dari dua kata yaitu. "informed" yang mengandung makna penjelasan atau keterangan (informasi), dan kata "consent" yang bermakna persetujuan atau memberi izin. Dengan demikian informed consent mengandung pengertian suatu persetujuan yang diberikan oleh pasien atau keluarganya setelah mendapat informasi tindakan medis yang akan dilakukan terhadap dirinya serta segala resikonya. Persetujuan pasien bagi setiap tindakan medik menjadi mutlak diperlukan, kecuali pasien dalam

Michael Daniel Mangkey, Op.Cit. Hlm.16-17.

12 Syahrul Machmud, Op.Cit. Hlm. 85 dan Hlm. 219. 
keadaan emergensi. Persetujuan tersebut dikenal dengan sebutan informed consent, sebab sebelum diberikan kepada pasien atau keluarganya (dalam hal pasien tidak cakap) harus diberikan informasi lebih dahulu mengenai beberapa hal dari tidndakan medik yang akan dilakukan. ${ }^{13}$

Sudah seharusnya informasi diberikan oleh dokter yang akan melakukan tindakan medik, sebab hanya ia sendiri yang tahu persis mengenai kondisi pasien dan segala seluk beluk dari tindakan medik yang akan dilakukan. Memang dapat didelegasikan kepada dokter lain atau perawat, namun jika terjadi kesalahan dalam memberikan informasi maka yang harus bertanggung jawab atas kesalahan itu adalah dokter yang melakukan tindakan medik. Lagi pula dalam proses mendapatkan persetujuan pasien, tidak tertutup kemungkinan terjadi diskusi sehingga memerlukan pemahaman yang memadai dari pihak yang memberikan informasi. ${ }^{14}$ Informed consent dapat dinyatakan secara lisan, bahkan dapat dinyatakan dengan sikap menyerah pada prosedur yang telah dispesifikasikan. ${ }^{15}$

Sehubungan dengan cara pernyataan kehendak menurut hukum, maka adanya informed consent dari pasien dapat dilakukan, antara lain :
a. dengan bahasa yang sempurna dan tertulis
b. dengan bahasa lisan yang sempurna secara lisan
c. dengan bahasa yang tidak sempurna asal dapat diterima oleh pihak lawan
d. dengan bahasa isyarat asal dapat diterima oleh pihak lawan

\footnotetext{
${ }^{13}$ Ibid. Hlm. 32

14 Sofwan Dahlan, op. cit. Hlm. 67.

${ }^{15}$ King Jr., J.H., The Law of Medikal Malpractice in a nutshell, West Publishing Co., St Paul, 1977, Hlm. 136.
} 
e. dengan diam atau membisu tetapi asal dipahami atau diterima oleh pihak lawan ${ }^{16}$

Permenkes 290/Menkes/PER/III/2008 yang berisi delapan bab dan enam belas pasal, mengatur tentang hal-hal yang berhubungan dengan pelaksanaan informed consent, berisi antara lain $:^{17}$

1. Kewajiban tenaga kesehatan memberikan informasi baik diminta maupun tidak diminta; diberikan secara adekuat tentang perlunya tindakan medik dan resiko yang dapat ditimbulkannya; diberikan secara lisan dan cara penyampaian informasi harus disesuaikan dengan kondisi dan situasi pasien, dalam arti dokter harus memberikan informasi selengkap-lengkapnya kecuali dokter menilai bahwa informasi yang akan diberikan merugikan pasien atau pasien menolak menerima informasi; dalam hal ini "informasi" dengan persetujuan pasien, dapat diteruskan kepada keluarga terdekat dari pasien didampingi oleh seorang perawat/paramedik.

2. Informasi yang diberikan mencakup keuntungan dan kerugian dari tindakan medik yang akan dilakukan, baik diagnostik maupun terapeutik, informasi cukup diberikan secara lisan, informasi harus diberikan secara jujur dan benar kecuali dokter menilai akan merugikan pasien dan informasi tersebut dengan persetujuan pasien akan diberikan kepada keluarga pasien.

3. Pemberi informasi adalah dokter yang bersangkutan dalam hal berhalangan dapat diberikan oleh dokter lain dengan pengetahuan dan tanggungjawab dari dokter yang bersangkutan, dibedakan antara tindakan operasi dan bukan operasi, untuk tindakan operasi harus dokter yang memberikan informasi, untuk bukan tindakan operasi sebaiknya oleh dokter yang bersangkutan, tetapi dapat juga oleh perawat/paramedik.

4. Jika perluasan operasi dapat diprediksi, maka informasi harus diberikan sebelumnya, dalam hal ini tidak dapat diprediksi sebelumnya, maka demi

\footnotetext{
${ }^{16}$ Veronica Komalawati, Peran Informed Consent dalam Transaksi Terapeutik: Persetujuan dalam Hubungan Dokter dan Pasien, Citra Aditya Bakti, Bandung 2002.

${ }^{17}$ Wila Chandrawila, Hukum Kedokteran, Mandar Maju, Bandung 2001, Hlm. 64.
} 
menyelamatkan jiwa pasien dapat dilaksanakan tindakan medik dan setelah dilaksanakan tindakan, dokter yang bersangkutan harus memberitahukan kepada pasien atau keluarganya.

5. Semua tindakan medik yang akan dilakukan terhadap pasien harus mendapat persetujuan dan persetujuan dapat diberikan secara tertulis maupun secara lisan, tetapi tindakan medik yang mengandung resiko tinggi harus dibuat persetujuan secara tertulis dan ditandatangani oleh yang berhak memberikan persetujuan.

6. Yang berhak memberikan persetujuan, adalah mereka yang dalam keadaan sadar dan sehat mental, telah berumur 21 tahun tetapi dibawah pengampuan maka persetujuan diberikan oleh wali/ pengampu, bagi mereka yang di bawah umur (belum 21 tahun dan belum menikah) diberikan oleh orang tua/wali.keluarga terdekat atau induk semang.

7. Bagi pasien yang dalam keadaan tidak sadar/pingsan dan tidak didampingi oleh keluarga terdekat dan secara medik memerlukan tindakan segera, tidak diperlukan persetujuan.

8. Terhadap dokter yang melaksanakan tindakan medik tanpa persetujuan, dikenakan sanksi administratif berupa pencabutan surat ijin praktek.

Penyampaian informasi harus disesuaikan dengan situasi dan kondisi dari pasien. Memang sangatlah ideal, kalau setiap dokter mau meluangkan sedikit waktunya untuk menyesuaikan diri dengan situasi dan kondisi dari pasien. Karena rutinitas pekerjaan biasanya dokter tidak lagi peka dengan situasi dan kondisi dari pasien. Kadang-kadang terdapat perbedaan persepsi antara pemberi jasa pelayanan kesehatan dan penerima jasa pelayanan kesehatan, yang menurut pasien sangat penting, menurut dokter tidak penting. ${ }^{18}$

2). Rekam medik

Selain informed consent, dokter juga berkewajiban membuat "Rekam Medik" dalam setiap kegiatan pelayanan kesehatan terhadap pasiennya. Pengaturan rekam medis terdapat dalam pasal 46 ayat (1) Undang-Undang praktik kedokteran. Rekam medis merupakan berkas yang berisi catatan dan dokumen tentang identitas

${ }^{18}$ Ibid.Hlm.34 
pasien, pemeriksaan, pengobatan, tindakan dan pelayanan yang di berikan kepada pasien. Rekam medis dibuat dengan berbagai manfaat, yaitu untuk pengobatan pasien, penigkatan kualitas pelayanan, pendidikan dan penelitian, pembiayaan, statistik kesehatan serta pembuktian masalah hukum, disiplin dan etik. Dasar pemikiran tersebut sesuai dengan pandangan filososfis yang menyatakan bahwa "patient pays the treatment, not the record". Oleh sebab itu sudah tepat jika pasal 12 ayat (1) Permenkes tentang Rekam Medik menegaskan bahwa berkas rekam medik milik sarana kesehatan. Yang agaknya sulit untuk dimengerti adalah bunyi ayat (2) dari pasal itu yang menyatakan bahwa isi rekam medis milik pasien. Sulit dipahami sebab dilihat dari sudut hukum, rekam medik merupakan doklumen karena berupa kertas yang berisi tulisan yang mengandung arti tentang sesuatu keadaan, kenyataan atau perbuatan. Sebuah dokumen tentunya tidak dapat dipisahkan dari isinya. ${ }^{19}$

Permenkes 269/MENKES/PER/III/2008, Bab V pasal 12

(1) Berkas rekam medis milik sarana pelayanan kesehatan

(2) Isi rekam medis merupakan milik pasien

(3) Isi rekam medis sebagaimana dimaksud pada ayat (2) dalam bentuk ringkasan rekam medis

(4) Ringkasan rekam medis sebagaimana dimaksud pada ayat (3) dapat diberikan, dicatat atau dicopy oleh pasien atau orang yang diberi kuasa atau atas persetujuan tertulis pasien atau keluarga pasien yang berhak untuk itu. ${ }^{20}$

Mengingat isi dari rekam medis merupakan data tentang pasien, sedangkan pasien sendiri berhak atas informasi maka konsekuensinya, pasien berhak :

a. Mengetahui isi rekam medis

\footnotetext{
${ }^{19}$ Sofwan Dahlan, Hukum Kesehatan, Rambu-rambu bagi Profesi Dokter, Badan Penerbit Universitas Dipenogoro, Semarang, 2003,Hlm. 78-81.

${ }^{20}$ Permenkes 269/MENKES/PER/III/2008, Bab V pasal 12.
} 
b. Menggunakan isi rekam medis untuk berbagai kepentingannya, misalnya untuk kelengkapan kalim asuransi

c. Memberikan persetujuan (konsen) atau menolak memberikan persetujuan kepada pihak lain yang ingin memanfaatkannya, baik individu atau lembaga (korporasi)

\section{Model Penyelesaian Masalah Sengketa Medis sebagai Upaya Mewujudkan Keadilan bagi Dokter di Indonesia}

Menyadari bahwa pelaksanaan penyelesaian sengketa medik yang selama ini berjalan, ternyata banyak salahnya, jauh dari kebenaran dan rasa keadilan, sehingga telah banyak merugikan dokter, Sedangkan negara dalam hal ini pemerintah mempunyai kewajiban untuk melindungi profesi dokter dalam menjalankan profesinya sebagaimana yang tertuang di dalam Undangundang Tenaga Kesehatan. Dengan demikian, diperlukan suatu konsep penanganan sengketa medik dengan mengedepankan cara alternatif penyelesaian sengketa diluar pengadilan (non ligitasi), yaitu dengan menerapkan cara-cara konsultasi, konsilisasi, negoisasi, dan penilaian ahli, dengan melibatkan pemerintah pusat dan pemerintah daerah yang diwakili oleh kementrian kesehatan dan dinas kesehatan, serta unsur-unsur organisasi profesi yang diwakili oleh IDI dan PDGI, serta kalangan masyarakat yang diwakili oleh LSM Kesehatan, Tokoh agama, serta tokoh masyarakat pemerhati kesehatan. Dalam peraturan perundang-undangan tidak ditemukan definisi ligitasi secara eksplisit. Namun, pada Pasal 6 ayat (1) UndangUndang Nomor 30 Tahun 1999 tentang Arbitase dan Alternatif Penyelesaian Sengketa (UUAAPS), menyatakan bahwa:

"Sengketa atau beda pendapat perdata dapat diselesaikan oleh para pihak melalui alternatif penyelesaian sengketa yang didasarkan pada itikad baik dengan mengenyampingkan penyelesaian secara ligitasi di pengadilan Negeri."

Dalam proses ligitasi menempatkan para pihak akan saling berlawanan satu sama lain, selain itu penyelesaian sengketa secara ligitasi merupakan sarana akhir (ultimum remidium) setelah alternatif penyelesaian sengketa lain 
tidak membuahkan hasil. ${ }^{21}$ Sesuai dengan Pasal 6 ayat (1) Undang - undang Arbitase dan Alternatif Penyelesaian Sengketa (UUAPS) tersebut, bahwa selain melalui pengadilan (ligitasi), penyelesaian sengketa juga dapat diselesaikan di luar pengadilan (non ligitasi), yang lazim dinamakan dengan Alternative Dispute Resolution (ADR) atau Alternatif Penyelesaian Sengketa (APS). ${ }^{22}$ Pasal 1 angka 10 Undang - undang Arbitase dan Alternatif Penyelesaian Sengketa (UUAPS), menyatakan bahwa yang dimaksud dengan alternatif penyelesaian sengketa adalah lembaga penyelesaian sengketa atau beda pendapat melalui prosedur yang disepakati oleh para pihak, yakni penyelesaian diluar pengadilan dengan cara konsultasi, negoisasi, mediasi, konsiliasi, atau penilaian ahli. Sedangkan arti dari arbitrase menurut Pasal 1 angka 1 Undang - undang Arbitase dan Alternatif Penyelesaian Sengketa (UUAPS) adalah cara penyelesaian suatu sengketa perdata di luar peradilan umum yang didasarkan pada perjanjian arbritase yang dibuat secara tertulis oleh para pihak yang bersengketa. ${ }^{23}$

Dalam praktik kedokteran sehari-hari yang selama ini terjadi, apabila ada dugaan malpraktik medik yang berujung terjadinya sengketa medik antara dokter dengan pasien dan/atau keluarga pasien, maka penyelesaian sengketa medik tersebut akan dapat diselesaikan secara normatif berdasarkan peraturan perundang-undangan melalui 2 cara yaitu: 1) Mengadukan permasalahan ke Majelis Kehormatan Disiplin Kedokteran Indonesia (MKDKI), sesuai dengan ketentuan Pasal 66 Undang-Undang Nomor 29 Tahun 2004 Tentang Praktek Kedokteran; dan 2) Melalui Pengadilan (ligitasi) dengan prosedur beracara sesuai hukum acara perdata maupun tuntutan pidana melalui pihak kepolisian dan hukum acara pidana. ${ }^{24}$

21 Frans Hendra Winarta, Hukum Penyelesaian Sengketa, Sinar Grafika, Jakarta, 2012. Hlm. 1-2.

22 Rachmadi Usman, Mediasi Di Pengadilan. Sinar Grafika, Jakarta, 2012. Hlm. 8.

${ }^{23}$ Rachmadi Usman, Op.cit,. Hlm. 8.

${ }^{24}$ Frans Hendra Winarta, Op.cit, HIm. 28 
Meskipun cara Pertama yaitu melakukan pengaduan ke Majelis Kehormatan Disiplin Kedokteran Indonesia (MKDKI) telah banyak dilakukan oleh pihak pasien dan/atau keluarga atas dugaan pelanggaran disiplin kedokteran, namun masih belum sepenuhnya efektif karena lembaga ini hanya satu-satunya di Indonesia dan keberadaanya pun hanya ada dijakarta saja, sehingga menyulitkan pasien dan juga dokter yang berada di daerah. ${ }^{25}$

Berdasarkan keterangan dari Majelis Kehormatan Disiplin Kedokteran Indonesia (MKDKI) bahwa dengan banyaknya aduan ke Majelis Kehormatan Disiplin Kedokteran Indonesia (MKDKI) akan tetapi keberadaan lembaga Majelis Kehormatan Disiplin Kedokteran Indonesia (MKDKI) itu sendiri yang hanya satu dan hanya berada di Kota Jakarta saja, sehingga tidak mengherankan terjadinya penumpukan perkara yang belum dapat diproses yang mencapai 97 kasus yang merupakan sisa kasus tahun 2015 yang seharusnya dapat diselesaikan tahun 2015 juga. Demikian juga dengan cara yang Kedua atau cara ligitasi, cara ini memiliki kendala yang tidak ringan, yakni terletak pada unsur beban pembuktian, lamanya waktu yang harus ditempuh, serta biaya yang tidak sedikit. Ditambah lagi dengan berbagai resiko lain seperti kemungkinan adanya gugatan balik atas pencemaran nama baik dan lain sebagainya. ${ }^{26}$

Di luar 2 cara tersebut diatas, ada cara lain atau cara Ketiga yang kerap kali dilakukan oleh dokter atau rumah sakit, yaitu dengan cara perdamaian sengketa medik dengan cara memberikan sejumlah uang sebagai tali kasih kepada pasien dan/atau keluarga pasien baik langsung maupun lewat pengacara, yang dilakukan oleh pihak rumah sakit sebagai institusi dimana dokter bekerja dan/atau oleh pihak dokter sendiri dengan atau tanpa bantuan pihak Ketiga yang bernegosiasi langsung dengan pasien atau keluarganya atau lewat pengacara. Cara Ketiga inilah, yang dianggap sebagai jalan keluar yang cukup efektif bagi pasien dan juga dokter atau rumah sakit sebagai

25 Rachmadi Usman, Op.cit,. Hlm. 9.

${ }^{26}$ Ibid, Hlm. 11. 
upaya menyelesaikan sengketa medis. ${ }^{27}$ Dokter dan rumah sakit tidak mau direpotkan dengan permasalahan ini, serta tidak siap untuk diexpose karena dapat menurunkan kepercayaan masyarakat, meskipun cara ini dapat dimanfaatkan oleh oknum yang ingin meraup keuntungan, tetapi cara ini dianggapnya dapat menguntungkan bagi penuntut (pasien) serta memiliki resiko paling ringan bagi Kedua belah pihak. ${ }^{28}$

Cara perdamaian sengketa medik dengan memberikan sejumlah uang kepada pasien atau keluarga pasien baik langsung maupun lewat pengacara seperti ini, akan memberikan efek pembelajaran yang tidak baik bagi masyarakat dan seyogyanya harusalah dihindari oleh dokter, karena dikhawatirkan pada masa mendatang dokter dan/atau rumah sakit akan dijadikan bahan pemerasan oleh pihak-pihak yang ingin memanfaatkan setiap ada sengketa medik yang sesungguhnya belum tentu merupakan kesalahan dokter. Dalam konsep hukum, cara ini lebih dikenal dengan istilah negosiasi yang kemudian berkembang menjadi bagian dari upaya penyelesaian sengketa di luar pengadilan (Alternative Dispute Resolution/ADR) atau Alternatif Penyelesaian Sengketa (APS).

Dalam hukum positif ketentuan mengenai pemanfaatan lembaga Alternatif Penyelesaian Sengketa (APS) ini telah diatur oleh Undang undang Arbitase dan Alternatif Penyelesaian Sengketa (UUAPS). Dalam Undang - undang Arbitase dan Alternatif Penyelesaian Sengketa (UUAPS) ini disebutkan bahwa penyelesaian sengketa yang termasuk di dalam APS antara lain konsultasi, negoisasi, mediasi, konsiliasi, atau penilaian ahli. ${ }^{29}$

Dengan demikian, mediasi yang dimaksud dalam Pasal 29 Undang undang Kesehatan, seyogyanya merujuk pada lembaga mediasi yang diatur di dalam Undang - undang Arbitase dan Alternatif Penyelesaian Sengketa

\footnotetext{
${ }^{27}$ Frans Hendra Winarta, Op. cit, Hlm. 62.

${ }^{28}$ Ibid, Hlm. 67.

${ }^{29}$ Ibid, Hlm. 88
} 
(UUAPS) tersebut. Namun Minimnya penjelasan dan sosialisasi keberadaan lembaga ini dalam upaya penyelesaian sengketa medis ternyata telah melahirkan banyak permasalahan, diantaranya bagaimana proses mediasi sengketa medik yang harus dilakukan, siapakah yang berwenang menjadi mediatornya, dan kemana serta dimana keberadaan lembaga Arbritase dan/atau lembaga APS sengketa medik ini, sedangkan kejadian sengketa medik itu sendiri sudah sering terjadi dan cenderung terus meningkat baik di kabupaten dan/atau kota dihampir seluruh wilayah Indonesia. ${ }^{30}$

Sementara di dalam Undang-Undang Nomor 44 Tahun 2009 Tentang Rumah Sakit tidak menyebutkan secara eksplisit tentang lembaga mediasi sebagai lembaga penyelesaian sengketa medis, namun di dalam Pasal 60 yang mengatur tentang tugas Badan Pengawas Rumah Sakit (BPRS) Provinsi disebutkan adanya kewenangan BPRS provinsi ini untuk melakukan upaya penyelesaian sengketa melalui jalan mediasi. Hal ini berarti bahwa sengketa medis yang terjadi di rumah sakit pun diupayakan untuk ditempuh melalui jalan mediasi. ${ }^{31}$

Hal ini didasari pemikiran bahwa sebagian besar sengketa medis terjadi di sebuah rumah sakit, sebagai institusi penyelenggara pelayanan kesehatan yang dilakukan oleh tenaga kesehatan termasuk dokter. Keberadaan lembaga mediasi sebagai lembaga penyelesaian sengketa di luar pengadilan diakui di dalam Undang-Undang Nomor 30 Tahun 1999 di dalam Pasal 1 ayat (10) yang menyebutkan bahwa APS adalah lembaga penyelesaian sengketa atau beda pendapat melalui prosedur yang disepakati para pihak yakni penyelesaian di luar pengadilan dengan cara konsultasi, negosiasi, mediasi, konsiliasi, atau penilaian ahli. ${ }^{32}$

\footnotetext{
${ }^{30}$ Frans Hendra Winarta, Opcit, Hlm. 71.

${ }^{31}$ Syahrul Machmud, Opcit, Hlm. 82.

${ }^{32}$ Ibid, Hlm. 88.
} 
Dalam demokrasi Negara Kesatuan Republik Indonesia (NKRI) yang berfalsafah Pancasila, penyelesaian berbagai masalah termasuk sengketa yang terjadi di masyarakat terlebih dahulu diselesaikan dengan cara musyawarah mufakat. Musyawarah berasal dari kata "syawara" yaitu berasal dari bahasa arab yang berarti berunding atau urun rembuk. Kewajiban musyawarah hanya untuk urusan keduniawian, jadi musyawarah adalah suatu upaya bersama dengan sikap rendah hati untuk memecahkan persoalan (mencari jalan keluar) guna mengambil keputusan bersama dalam penyelesaian atau pemecahan masalah yang menyangkut urusan keduniawian. ${ }^{33}$ Dalam menyelesaikan permasalahan dugaan malpraktik medik terhadap profesi dokter yang selalu berujung dengan sengketa medik. Penentuan adanya malpraktik medik atas dugaan adanya kesalahan dan/atau kelalaian dokter dalam menjalankan profesinya masih menjadi hal yang masih diperdebatkan diantara penegak hukum, profesi dokter, dan masyarakat. Sehingga musyawarah mufakat harus menjadi suatu hal penting dan utama dalam menyelesaikan permasalahan malpraktik medik tersebut sebagai bentuk perlindungan bagi dokter sebagai subjek yang dipersalahkan. Terlebih lagi bangsa Indonesia yang telah menyatakan dirinya sebagai negara hukum (rechtaat) yang salah satu unsurnya adalah asas praduga tak bersalah (presumption of innocence). Pernyataan malpraktik medik dari masyarakat merupakan suatu contoh pelanggaran asas praduga tak bersalah, karena kesalahan dan/atau kelalaian yang disangkakan tersebut belum dibuktikan.

Menurut laporan dari Majelis Kehormatan Disiplin Kedokteran Indonesia (MKDKI) bahwa permasalahan yang diadukan oleh pasien atau keluarga pasien kepada MKDKI, sebagian besar (59\%) akibat komunikasi yang tidak lancar. Dikaitkan dengan Pasal 29 Undang - undang Kesehatan yang menyatakan bahwa dugaan kelalaian dokter dalam menjalankan profesinya harus diselesaikan terlebih dahulu melalui mediasi, dan juga dengan Pasal 78 Undang -undang Tenaga Kesehatan yang menyatakan bahwa

33 https://wikipedia.org/wiki/musyawarah, diakses pada tanggal 25 Februari 2017. 
dugaan kelalaian dokter dalam menjalankan profesinya harus diselesaikan terlebih dahulu melalui penyelesaian sengketa diluar pengadilan pada dasarnya adalah memperbaiki komunikasi berdasarkan pada praduga tak bersalah melalui suatu musyawarah untuk mufakat. ${ }^{34}$ Perlindungan hukum terhadap profesi dokter atas dugaan malpraktik medik sebagaimana telah diamanatkan oleh Undang-undang tersebut di atas perlu segera diimplementasikan dalam sebuah konsep penyelesaian yang berdasarkan pada praduga tak bersalah melalui musyawarah mufakat dengan cara komunikasi yang baik dan benar.

Batasan praktik profesi dokter sesungguhnya telah memenuhi persyaratan, karena sudah tercantum dan telah mengikuti koridor hukum yang sudah ada di dalam Undang - Undang Praktek Kedokteran (UUPK). Koridor hukum tersebut mencakup syarat materil, yang diberikan oleh institusi pendidikan kedokteran berupa ijazah dan sumpah dokter, juga syarat formil yang diberikan oleh Konsil Kedokteran Indonesia (KKI) berupa Surat Tanda Registrasi (STR) yang sudah mencakup kewenangan dokter untuk melakukan praktik profesinya, disamping itu ada syarat formil lainnya adalah Surat Izin Praktik (SIP) yang dikeluarkan oleh dinas kesehatan kota dan/atau kabupaten. Setelah dokter memenuhi syarat materil dan formil yang menjadi dasar melakukan praktik kedokteran, ada syarat lain yang harus dipenuhi oleh dokter yaitu dokter harus mengikuti SPM dan SOP yang berlaku ditempat dokter melakukan praktik kedokterannya. ${ }^{35}$

Syarat-syarat tersebut seyogyanya dapat dijadikan atau merupakan alasan pembenar (penghapus pidana) bagi dokter yang diduga melakukan tindakan malpraktik medik. Sehingga apabila dalam melakukan praktik kedokteran muncul kejadian yang tidak diharapkan atau resiko medik, meskipun pasien mempunyai hak menggugat, menuntut atau mengadukan dokter sebagaimana tertuang dalam Pasal 66 UUPK, maka seyogyanya

\footnotetext{
${ }^{34}$ Ibid, Hlm. 70.
}

${ }^{35}$ Ibid, Hlm. 102. 
penegak hukum tidak boleh serta merta menyidik dan menjadikan dokter sebagai tersangka karena dokter belum dapat dikategorikan telah memenuhi unsur perbuatan melawan hukum. Dengan demikian, selama dokter dalam menjalankan profesinya sesuai koridor hukum, maka dalam ketentuan pidana di Indonesia, dokter tersebut selain mendapatkan alasan pembenar yang menghapuskan sifat melawan hukumnya perbuatan, sehingga apa yang dilakukannya oleh dokter lalu menjadi perbuatan yang patut dan benar, juga dokter mendapatkan alasan pemaaf yaitu alasan yang dapat memaafkan sifat perbuatan dokter, meskipun perbuatan tersebut melawan hukum. ${ }^{36}$

Dalam situasi peradilan mengenai sengketa medik atas dugaan malpraktik medik yang tidak normal dan bersifat semu tersebut, sehingga keputusan yang dihasilkan pun akan bersifat semu juga, serta keadilan dan kebenaran yang dihasilkannya pun akan bersifat semu pula yang pada akhirnya merugikan semua pihak. Apalagi dalam sebuah negara hukum modern termasuk Indonesia, yang memberikan kewenangan yang luas kepada pemerintah untuk mencampuri kehidupan warga negaranya agar terwujud kebenaran yang berkeadilan serta untuk kesejahteraan warga negara itu sendiri, karena itu diperlukan perlindungan hukum bagi warga negara atas tindakan hukum negara yang dilaksanakan oleh pemerintah.

Berdasarkan pertimbangan hal tersebut diatas, maka negara yang diwakili oleh pemerintah, perlu membuat suatu aturan mengenai perlindungan terhadap profesi dokter terkait dengan berbagai hal yang berhubungan dengan pelaksanaan praktik kedokteran, termasuk juga perencanaan kebutuhan, pengadaan, pendayagunaan, pembinaan, dan pengawasan mutu dokter Indonesia demi untuk suksesnya pembangunan bangsa dan negara tercinta ini. Konsep peraturan tentang perlindungan profesi dokter ini pada dasarnya untuk melindungi hak dokter maupun hak masyarakat pengguna jasa dokter, mempertahankan dan meningkatkan mutu penyelenggaraan upaya kesehatan oleh dokter, serta untuk memenuhi

\footnotetext{
${ }^{36}$ Fuad Usha, Moh Najih, Tongat, Pengantar Hukum Pidana, UMM Press, Malang, 2004, Hlm. 194.
} 
kebutuhan masyarakat akan dokter yang benar-benar berkompeten secara ilmu kedokteran dan juga secara etika. Disamping itu, konsep peraturan tentang perlindungan profesi dokter ini juga harus didasari kepada: perikemanusiaan, manfaat, etika profesi kedokteran, perhormatan terhadap hak, dan kewenangan, keadilan, pengabdian, norma agama dan perlindungan bagi semua. ${ }^{37}$

Model Perlindungan hukum dan tanggungjawab bagi dokter yang ideal perlu memperhatikan pihak-pihak yang terlibat dalam kinerja dokter terhadap pasien. Di mana dalam suatu Rumah Sakit, kinerja dokter juga dipengaruhi oleh tenaga medis lainnya. Namun dalam penelitian ini tidak dibahas mengenai sifat ketergantungan dari tenaga medis terhadap kinerja dokter. Melainkan perlunya sebuah model perlindungan hukum dan tanggungjawab yang dibentuk dengan sistematis dan sesuai dengan rasa keadilan bagi para pihak. Melalui pengakuan dan tanggung jawab Negara terhadap dokter Indonesia, maka dokter memiliki kedudukan yang jelas dalam bidang pekerjaannya. Dimana dokter adalah profesi yang penuh resiko dan perlu mendapatkan posisi tawar yang berbeda namun tetap bertanggung jawab. ${ }^{38}$ Negara melalui fungsi legislatif membuat seperangkat peraturan perundang-undangan yang menutup celah kriminalisasi dokter karena suatu sengketa medis. Dengan memperhatikan hubungan antara dokter, pasien, dan rumah sakit agar tidak merugikan salah satu pihaknya. Perlindungan ini merupakan langkah kongkrit pemerintah sebagai negara yang menganut aliran hukum positif.

Status dokter yang sudah diakui oleh negara lengkap dibentuknya peraturan perundang-undangan terkait yang mengakomodir hak dan kewajiban antara dokter, pasien, dan rumah sakit akan memberikan sebuah kondisi dimana rumah sakit akan concern memberikan perlindungan aktif bagi dokternya (apapun status dokternya). Ketiga upaya di atas adalah

${ }^{37}$ Frans Hendra Winarta, Opcit, Hlm. 106.

${ }^{38}$ Ibid 109. 
bentuk upaya preventif dari sengketa medis. Namun apabila suatu ketika sengketa medis tersebut tidak dapat dihindari, maka penyelesaian yang harus didahulukan adalah melalui Alternative Dispute Resolution, Ini merupakan langkah yang bersifat aman bagi dokter, pasien dan rumah sakit.

Untuk mengetahui apa yang adil dan apa yang tidak adil terlihat bukan merupakan kebijakan yang besar, lebih-lebih lagi jika keadilan diasosiasikan dengan aturan hukum positif, bagaimana suatu tindakan harus dilakukan dan pendistribusian menegakkan keadilan, serta bagaimana memajukan keadilan. Namun tentu tidak demikian halnya jika ingin memainkan peran menegakkan keadilan. Rawls berpendapat bahwa yang menyebabkan ketidakadilan adalah situasi sosial sehingga perlu diperiksa kembali mana prinsip-prinsip keadilan yang dapat digunakan untuk membentuk situasi masyarakat yang baik. ${ }^{39}$

Pada sengketa medis yang dihadapi dokter kepada pasien terkadang memiliki konsekuensi yang berat bagi ke dua belah pihak. Misalkan bagi pasien yang mengalami cacat permanen atau dokter yang reputasinya memburuk akibat terlibat sengketa dengan pasiennya. Dirasa kurang adil ketika dokter tersebut telah melaksanakan tugasnya sesuai dengan Standar Operasional dan Prosedur tetapi terjadi kejadian yang tak diinginkan. Maka seperti yang disampaikan oleh John Rawls di atas, apabila dokter telah melakukan segala upaya dengan kewajiban moral dan profesionalnya, maka dia berhak mendapatkan keadilan sebagaimana nanti terjadi sengketa medik. Lalu berkaitan dengan tanggung jawab yang menurut Sugeng Istanto, pertanggungjawaban berarti kewajiban memberikan jawaban yang merupakan perhitungan atas semua hal yang terjadi dan kewajiban untuk memberikan pemulihan atas kerugian yang mungkin ditimbulkannya

Hal ini menjadi rancu seharusnya dokter mendapat perlindungan secara aktif oleh Rumah Sakit selaku fasilitator, namun menjadi pihak individu yang bersengketa dengan pasien. Maka dengan demikian perlu diperhatikan konsep

${ }^{39}$ Ibid, Hlm. 66. 
tanggung jawab yang dikerjakan bersama-sama oleh Rumah Sakit dan Dokter ketika terjadi sengketa medik dengan pasiennya. Hubungan dokter-pasien yang dibangun atas dasar hubungan saling percaya dalam upaya penyembuhan tidak jarang menimbulkan konflik kepentingan antara dokterpasein. Konflik kepentingan ini bila tidak diselesaikan dengan baik maka tidak mustahil hukum akan menjadi pilihan dalam penyelesaian sengketa medis tersebut.

Sengketa medis yang diselesaikan melalui jalur hukum sebetulnya tidak perlu ada, karena landasan hubungan dokter- pasien berawal/dibangun atas dasar hubungan saling percaya maka idealnya peneyelesaian melalui pengadilan bukan menjadi pilihan bijak dalam penyelesaian sengketa medis tersebut. Namun kenyataannya tidak demikian halnya karena tidak jarang pangadilan menjadi pilihan penyelesaian sengketa medis antara dokter pasien maka timbulah reaksi atau tantangan dari kalangan profesi medis. Mereka menilai hukum terlalu jauh mencampuri otonomi profesi medis. Berkenaan dengan itu, untuk mengatasi problema di atas maka tawaran solusi penyelesaian sengketa medis adalah melalui pembentukan peradilan profesi di mana hakim anggotanya dilibatkan profesi medis di dalamnya, sehingga tidak lagi dituding bahwa hakim pengadilan umum tidak memahami persoalan kedokteran. Dengan begitu cara penyelsaian sengketa medis dapat tercapai. Implikasi bagi Rumah Sakit dan Tenga Kesehatan ${ }^{40}$

Undang-undang Rumah Sakit dibuat untuk memberikan kepastian dalam penyelenggaraan pelayanan kesehatan, maupun memberikan perlindungan bagi masyarakat dan perlindungan bagi sumber daya di rumah sakit. Dalam UU Rumah Sakit telah menentukan bahwa rumah sakit akan bertanggungjawab secara hukum, jika terjadi kelalaian tenaga kesehatan yang menyebabkan kerugian bagi masyarakat atau pasien. Namun demikian berdasarkan uraian di atas, ketentuan ini menurut penulis dapat menimbulkan banyak implikasi praktis atau implikasi aplikasinya, sehubungan dengan

\footnotetext{
${ }^{40}$ Syahrul Machmud, Opcit, Hlm. 81.
} 
ketentuan Pasal 46 UU Rumah Sakit tersebut. Impli-kasi dengan adanya, ketentuan rumah sakit bertanggung jawab secara hukum atas kelalaian tenaga kesehatan, akan dicoba disebutkan di bawah ini.

Adanya ketentuan rumah sakit bertanggungjawab atas kerugian seseorang sebagai akibat tindakan tenaga kesehatan, hal ini sebagai permintaan agar rumah sakit bertanggungjawab atas tindakan yang dilakukan oleh petugas profesi bawahannya baik sebagai status tetap maupun tidak tetap, kecuali bagi mereka yang menjalankan tugas profesi sebagai tamu (visitor). Selain itu, ketentuan tentang tanggung jawab rumah sakit ini dimaksudkan agar ada jaminan ganti rugi yang harus didapatkan oleh penderita, dan sebagai kontrol agar rumah sakit melakukan penghati-hati. Dengan adanya ketentuan rumah sakit bertanggungjawab terhadap kelalaian tenaga kesehatan ini, merupakan genderang pembuka bahwa rumah sakit terbuka bagi masyarakat untuk digugat jika masyarakat merasa dirugikan karena tindakan kelalaian tenaga kesehatan. ${ }^{41}$

Sebagai tindak lanjut dari dari ketentuan ini, maka rumah sakit akan melakukan beberapa hal. Pertama, membentuk seperangkat pembantu direktur seperti komisi hukum, untuk menangani aspek-aspek hukum yang berhubungan dengan urusan kesalahan profesi atau berbagai penyimpangan sebagai keadaan darurat (nood-toestand); Kedua, melakukan akreditasi terhadap sumber-sumber daya tenaga profesi dan daya kerja kesehatan.

Akreditasi dilaksanakan secara terbuka bagi masyarakat untuk kepentingan peningkatan pelayanan kualitas pelayanan kesehatan; Ketiga, memenuhi hak-hak asasi pasien yang terdiri dari hak informasi, hak untuk memberikan persetujuan, hak atas rahasia kedokteran, hak atas pendapat Kedua; dan ke-empat, melaksanakan doktrin kesehatan yaitu pengadaan rekam medik (medikal record), mengadakan hak persetujuan tindakan medis (informed concent) dan penertiban rahasia kedokteran (medikal secrecy). Hal ini dilakukan untuk menentukan kejelasan dan standarisasi bentuk

${ }^{41}$ Ibid, Hlm. 118. 
formulasinya yang beraneka ragam, serta dengan pengecualiannya. Kejelasan dalam hal rekam medik diperlukan sehingga diketahui cara-cara yang telah dilakukan dan akan kelihatan tindakan kelalaian yang telah terjadi ataupun telah terjadi tindakan akibat adanya resiko medis. ${ }^{42}$

\section{C.PENUTUP}

\section{Kesimpulan}

1. Implementasi dari pelaksanaan tanggung jawab rumah sakit terhadap dokter dalam Undang - undang tersebut berbeda - beda, tergantung dari status kepegawaian / ketenagakerjaan dokter, kontrak kerjasama yang telah disepakati antara pihak rumah sakit dengan dokter, status rumah sakit sebagai suatu badan hukum atau korporasi, regulasi, peraturan, keputusan serta ketetapan internal rumah sakit, kebijakan pemerintah daerah setempat, peran organisasi profesi dan masyarakat yang terlibat secara langsung dalam bidang kesehatan. Konsep penanganan sengketa medik yang ada selama ini, disamping menggunakan cara litigasi, dilakukan juga dengan mengedepankan cara alternatif penyelesaian sengketa diluar pengadilan (non ligitasi), yaitu dengan menerapkan cara-cara konsultasi, konsilisasi, negoisasi, dan penilaian ahli, dengan melibatkan semua pihak dalam upaya mewujudkan keadilan agar terdistribusi merata sesuai teori keadilan distributif dari Aristoteles yang menempatkan dokter, pasien, serta rumah sakit dalam kedudukan yang sejajar.

2. Model yang dapat diterapkan dalam rangka perlindungan hukum dan tanggungjawab rumah sakit terhadap dokter dalam sengketa medik adalah Model yang adil menurut hukum, dokter dibekali kode etik kedokteran, standar profesi, hak asasi manusia, fungsi sosial serta peraturan-peraturan yang mengatur praktik kedokteran; dan rumah sakit harus mempunyai berbagai aturan untuk melindungi pasien dari praktek rumah sakit yang tidak layak beroperasi, melindungi tenaga kesehatan dari bahaya yang

${ }^{42}$ Ibid, Hlm. 231 
ditimbulkan oleh rumah sakit, melindungi masyarakat dari dampak lingkungan rumah sakit, mengendalikan fungsi rumah sakit kearah yang benar, meningkatkan mutu rumah sakit, menselaraskan layanan dirumah sakit dengan program pemerintah dalam bidang kesehatan; serta pasien memiliki hak asasi untuk menetukan nasib sendiri (the right to self determination) dan hak atas informasi (the right to information).

\section{Saran}

1. Rumah sakit sebaiknya memiliki Good Governmence (Hospital Bylaws, Coorporate Bylaws, Medical Staf Bylaws). Rumah sakit perlu mematuhi peraturan yang telah ada dan melaksanakan standarisasi pelaksanaan Standar Operasional Prosedur (SOP), Standar Pelayanan Minimal (SPM), Clinical Pathway, standar akreditasi dan lain - lain dalam semua lini pelayanan. Hal ini dilakukan untuk meminimalisir terjadinya kesalahan pelayanan yang berujung pada sengketa medis. Seandainya terjadi sengketa, Rumah Sakit wajib berperan secara proaktif untuk menjalankan amanat Undang-undang dengan mengedepankan penyelesaian non litigasi yang sampai saat ini dirasakan lebih efektif dalam penyelesaian sengketa medis yang terjadi antara dokter, pasien dan rumah sakit, serta perlunya dilakukan kajian sinkronisasi secara mendalam terhadap Undang - Undang Praktek Kedokteran, Undang - Undang Kesehatan, Undang - Undang Rumah Sakit serta Undang - Undang Tenaga Kesehatan.

2. Health and safety regulation memerlukan standar tertentu untuk menyelesaikan konflik antara patients preferences dan professional standard of care. Komitmen mutu perlu dikongkritkan dengan membuat pernyataan tentang mutu (quality statement). Quality statement mempunyai Vision statement dan Mission statement. Pemerintah dalam fungsinya sebagai eksekutif dapat mengusulkan terhadap lembaga legislatif untuk membentuk peraturan yang baru guna menutup celah terhadap dokter untuk dikriminalisasi serta peraturan tentang rumah sakit kaitannnya dalam sengketa medis yang terjadi mengingat transaksi yang ada adalah berbeda dengan transaksi untuk prikatan / perjanjian lain pada umumnya. Transaksi 
terapeutik merupakan perikatan / perjanjian berdasarkan upaya (inspaning verbintennis) bukan perikatan berdasarkan pada hasil (resultaat verbintenis). 


\section{A. Buku}

\section{DAFTAR PUSTAKA}

Alexandra Indriyanti Dewi, Etika dan Hukum Kesehatan, Pustaka Book Publisher, Yogyakarta, 2008.

Abdul Wahab Bakri, Kapita Selekta Hukum Medik, Fakultas Hukum Universitas Islam Bandung, Bandung, 1998.

Budi Sampurna, Kumpulan Makalah Seminar Sehari : Informasi Kesehatan dalam Pembuktian Dugaan Malpraktek, Jakarta,2005.

Dona Budi Kharisma, Aspek Hukum Hubungan Antara Dokter Dengan Rumah Sakit Dalam Perjanjian Terapeutik Di Rumah Sakit Dr. Moewardi Surakarta, Skripsi, UNS, 2008.

Endang Wahyati Yustina, Mengenal Hukum Rumah Sakit, Keni Media Bandung, 2012.

Frans Hendra Winarta, Hukum Penyelesaian Sengketa, Sinar Grafika, Jakarta, 2012.

King Jr., J.H., The Law of Medikal Malpractice in a nutshell, West Publishing Co., St Paul, 1977

Rachmadi Usman, Mediasi Di Pengadilan. Sinar Grafika, Jakarta, 2012.

Soekidjo Notoatmodjo, Etika dan Hukum Kesehatan, Rineka Cipta, 2010.

Soerjono Soekanto \& Sri Mamudji, Penelitian Hukum Normatif (Suatu Tinjauan Singkat), Rajawali Pers, Jakarta, 1985.

Mukti Fajar dan Yulianto Achamd, Dualisme Penelitian Hukum Normatif dan Empiris, Pustaka Pelajar, Yogyakarta, 2010, Hlm. 138.

Veronica Komalawati, Peran Informed Consent dalam Transaksi Terapeutik: Persetujuan dalam Hubungan Dokter dan Pasien, Citra Aditya Bakti, Bandung 2002.

Wila Chandrawila, Hukum Kedokteran, Mandar Maju, Bandung 2001

Sofwan Dahlan, Hukum Kesehatan, Rambu-rambu bagi Profesi Dokter, Badan Penerbit Universitas Dipenogoro, Semarang, 2003. 
Wila Chandrawila Supriadi, Makalah yang dipresentasikan pada Seminar Kode Etik Kedokteran, Undang-Undang Praktik Kedokteran dan Dugaan Malpraktek Medis, Bandung, 2004.

\section{B. Peraturan Perundang-Undangan}

Undang-Undang No 29 Tahun 2004 Tentang Rumah Sakit

Undang-Undang Nomor 36 Tahun 2009 tentang Kesehatan

\section{Internet}

Ray Pratama Saidarai, Hubungan Pasien, Dokter dan Rumah Sakit, 2004, http://raypratama.blogspot.co.id/2014/11/hubungan-pasien-dokter-dan-rumahsakit.html, di akses pada tanggal 14 Desember 2015.

Tempo. Co, Hakim PK MA Bebaskan Dokter Ayu

http://www.tempo.co/read/news/2014/02/07/063551992/Hakim-PK, Jakarta, diakses 24 Maret 2014. 